\title{
Sheep Gait Biomechanics and the Assessment of Musculoskeletal Conditions: A Systematic Review
}

\author{
Rui Silva ${ }^{1, a^{*}}$, Ivo Santos Dimas ${ }^{2, b}$, Justin W. Fernandez ${ }^{3, c}$, Nuno Alves ${ }^{1, d}$, \\ Pedro Morouço ${ }^{1, \mathrm{e}}$, Ana Colette Maurício ${ }^{4,5, \mathrm{f}}$, António Veloso ${ }^{6, \mathrm{~g}}$ \\ and Sandra Amado $1,2,6, \mathrm{~h}$ \\ ${ }^{1}$ Centre for Rapid and Sustainable Product Development, Polytechnic Institute of Leiria, Leiria, \\ Portugal \\ ${ }^{2}$ Higher School in Health, Polytechnic Institute of Leiria, Leiria, Portugal \\ ${ }^{3}$ Department of Engineering Science and Auckland Bioengineering Institute, University of \\ Auckland, New Zealand \\ ${ }^{4}$ Departamento de Clínicas Veterinárias, Instituto de Ciências Biomédicas de Abel Salazar \\ (ICBAS), University of Porto (UP), Porto, Portugal
}

${ }^{5}$ Centro de Estudos de Ciência Animal (CECA), Instituto de Ciências, Tecnologias e Agroambiente (ICETA), University of Porto (UP), Porto, Portugal

${ }^{6}$ Faculty of Human Kinetics, Center for Interdisciplinary Study of Human Performance, University of Lisbon, Portugal.

arui.d.silva@ipleiria.pt, bivodimas@gmail.com, cj.fernandez@auckland.ac.nz, dnuno.alves@ipleiria.pt, epedro.morouco@ipleiria.pt, fana.collete@hotmail.com, gapveloso@fmh.ulisboa.pt, 'sandra.amado@ipleiria.pt

Keywords: osteoporosis, sheep, gait analysis, therapy, biomechanics

\begin{abstract}
In recent years, sheep have been reported as the ideal animal model to study osteoporosis, hence it is important to identify instruments, tools and ideal parameters needed to assess the effects of different treatments. In previous studies conducted in other animal models with osteoporosis, the most common parameters used for evaluation concerned primarily bone properties, such as the dual $\mathrm{X}$-ray absorptiometry. However, biomechanical gait analysis as an integrative functional parameter and a non-invasive method, will be an important tool in research and clinical applications. This research review was performed using the PubMed database and included studies related to sheep with outcome measures concerning functional performance assessed during gait in vivo; and excluded studies related with cardiovascular disease and sperm properties, which include other animal species, with outcomes not related with functional locomotor evaluation. Only studies related with bone properties were analyzed. The most frequent and relevant included parameters were the following: mean peak vertical ground force reaction, gait cycle and stance/swing phase duration, percentage of stance/swing phase in a gait cycle, stride length and the stifle joint angles during a gait cycle. Gait biomechanical parameters have been established for the assessment of some clinical orthopedic condition using sheep models but not currently for osteoporosis.
\end{abstract}

\section{Introduction}

The sheep is the preferred animal to study human musculoskeletal conditions due to its body size and musculoskeletal mechanical characteristics being more comparable to those of the human. For example, the presence of Haversian channels and the phenomena of cortical remodeling in its bone structure, its phylogenetic proximity to the human species, their reproductive capacity and their generally docile and cooperative temperament [1]. Hence, sheep musculoskeletal models are a suitable animal model, but despite these similarities, to date, there are no studies that relate the sheep model with metabolic diseases in the musculoskeletal system, such as osteoporosis. 
Due to associated complications of osteoporosis and related bone fractures, this disease is presenting a major public health burden [2]. Various animal models have been established and used to investigate the pathogenesis of osteoporosis and to facilitate the preclinical testing of new experimental drug therapy treatments, such as antiresorptive drugs [2]. Animal models' are currently used for the demonstration of benefit of any new modality sufficiently different from the standard treatment [2]. Animal models provide more uniform experimental material and allow a comprehensive study of potential therapies [3]. This minimizes the limitations associated with studying the disease in humans, namely the diversity in their lifestyles [3]. Moreover, high costs and long duration of clinical trials make the animal model very feasible for the study of osteoporosis upon [4].

Thus, to assess the effect of a treatment in sheep with osteoporosis, most of the studies conducted in other animals, use parameters related with bones properties, essential to measure bone mineral density and diagnosis osteoporosis, but this only give us information about the bone structure and does not evaluate the functional impairment [5,6]. Due to this limitation, and since sheep have been identified as ideal for studies related to osteoporosis [4], it's important to identify functional biomechanical outcome measures that could also be used to assess the effects of new therapies on these animals, similar to completed studies with rats [7-11].

In sheep, gait is an important function of animals and engages all behaviors, such as active foraging for food sources, movement to avoid a stressful environment, and finding a mate [12]. Hence, gait analysis being a functional parameter and a non-invasive method, could be an important biomechanical tool in research and clinical applications, as an outcome indicator to guide the course of treatment [13], and to compare the effects of alternative therapies [13,14]. Thus, in this review we identify the biomechanical outcome measures that have been reported to relate to sheep gait assessment.

\section{Materials and Methods}

Search Strategy. To identify the articles that may be included in this review, the Database used was PubMed, and the terms were "kinematic(s)", "ovine", "sheep" and "gait".

The combinations of the terms used were: ["kinematic" and "sheep"] $(\mathrm{N}=44)$, ["kinematics" and "sheep"] $(\mathrm{N}=60)$, ["gait" and "sheep"] $(\mathrm{N}=139)$, ["kinematics" and "ovine"] $(\mathrm{N}=33)$, and ["kinematic" and "ovine"] $(\mathrm{N}=20)$. No restrictions were applied to year or publication type.

Eligibility Criteria. Inclusion and exclusion criteria for this systematic review were determined a priori.

Inclusion criteria were studies (1) related to sheep and studies (2) with outcome measures related with in vivo physical / functional performance assessed during gait.

Exclusion criteria were studies (1) related with cardiovascular disease and sperm properties, studies that (2) include other animals (unless sheep, lambs, ewe or ram) in their study population; and studies (3) with outcomes measures not related with limbs evaluation, (4) based on in vitro gait analysis (robot) and also (5) have only evaluated bone properties.

Data extraction and quality appraisal. After removal of the excluded articles based on PRISMA, data extraction was standardized according to the following terms: (i) first author and year, (ii) aim of the study, (iii) population number, (iv) measurement tools, and the (v) functional parameters evaluated.

To assess the quality of the articles included, it's necessary to consider that in studies with animal models there is a guideline to follow named ARRIVE, created in 2010. This guideline consists of the minimum information that all scientific publications reporting research using animals should include, such as the number and specific characteristics of animals; details of housing and husbandry; experimental, statistical, and analytical methods. All the items in the checklist (20) should be included to promote high-quality, comprehensive reporting to allow an accurate critical review of what was done and what was found [15]. 


\section{Results}

Fig 1 summarizes the results of the different steps to identify appropriate articles for the review, based on PRISMA guidelines [16]. The database search identified 296 articles, and after duplicate removal, 204 were considered potentially relevant and were screened for relevant content. From them, 59 were excluded for no available access and 136 based on the title and the abstract (articles with "spermatozoon" or "sperm "or "semen" or "spermatozoa" and related with cardiovascular disease), and 105 were retrieved for full-text assessment of eligibility. In the next phase, 77 of the 105 full-text articles were excluded based on the exclusion criteria, specifically studies with outcomes not related with limbs evaluation $(n=38)$, based on in vitro gait analysis $(n=12)$ and with only bone properties evaluated $(n=25)$.

Thus, in this review were included 28 articles that were evaluated based on the ARRIVE guidelines. Considering that this guideline was created recently, it was possible to realize that many of the studies do not yet present all the items. However, none of the studies were excluded from the review because the objective of the review is to identify which parameters were considered by the authors and not the content of the articles (Table 1).

Table 1: Arrive Guidelines - Application

\begin{tabular}{|c|c|c|c|c|c|c|c|c|c|c|c|c|c|c|c|c|c|c|c|c|c|}
\hline \multirow{3}{*}{ Articles } & \multicolumn{21}{|c|}{ Checklist ARRIVE } \\
\hline & $\mathrm{T}$ & A & & E्. & \multicolumn{9}{|c|}{ Methods } & \multicolumn{4}{|c|}{ Results } & \multicolumn{3}{|c|}{$\begin{array}{l}\text { Discussion/ } \\
\text { Conclusion }\end{array}$} & \multirow[t]{2}{*}{$\begin{array}{l}\vec{U} \\
\mathscr{W}\end{array}$} \\
\hline & 1 & 2 & 3 & 4 & 5 & 6 & 7 & 8 & 9 & 10 & 11 & 12 & 13 & 14 & 15 & 16 & 17 & 18 & 19 & 20 & \\
\hline Duda et al.[17] & & \multirow{18}{*}{ 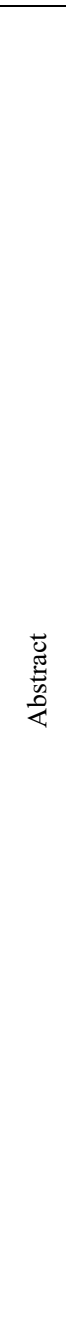 } & $1-6$ & 7 & 1 & 1 & $1-9$ & 1 & 2 & 1 & 1 & 6 & $5-9$ & - & - & $1-2$ & - & 1,6 & 6,7 & no & \multirow{18}{*}{ 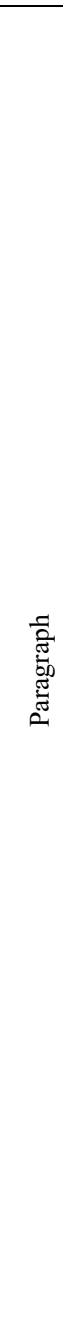 } \\
\hline $\begin{array}{l}\text { Tapper et } \\
\text { al.[18] }\end{array}$ & & & 1,2 & 3 & 2 & 3 & $1-4$ & 2 & - & 3 & - & $5,6,8$ & $5-8$ & - & - & $1-4$ & - & $1-3$ & 4 & no & \\
\hline $\begin{array}{l}\text { Kaspar et } \\
\text { al.[19] }\end{array}$ & & & $\begin{array}{c}1,2, \\
5\end{array}$ & 7 & 3 & 2 & $4-7$ & 2 & 8 & 11 & - & $\begin{array}{c}11-13 \\
17\end{array}$ & 18 & 1 & 2 & $3-9$ & - & 1 & 9 & yes & \\
\hline $\begin{array}{l}\text { Oddy et } \\
\text { al.[20] }\end{array}$ & & & 1,2 & 2 & 2 & 2 & $1,2,5$ & 2 & 2 & 2 & 4 & $3,4,6$ & 7 & 1 & 2 & 2,3 & - & 2 & 5 & yes & \\
\hline $\begin{array}{l}\text { Seebek et } \\
\text { al.[13] }\end{array}$ & & & $1-3$ & 4 & 2 & 3 & $4-6$ & 6 & - & 7,8 & 14 & 1 & 16 & - & - & $\begin{array}{l}2-4, \\
6,7 \\
\end{array}$ & - & 1 & $10-14$ & yes & \\
\hline $\begin{array}{l}\text { Pendegrass et } \\
\text { al.[21] }\end{array}$ & & & $1-3$ & 4 & 2 & 4 & 4 & $5-7$ & - & 6 & - & 6 & 8 & - & 2 & \begin{tabular}{|c|}
3,5 \\
6 \\
\end{tabular} & - & 1,2 & 7 & yes & \\
\hline $\begin{array}{l}\text { Tapper et } \\
\text { al.[22] }\end{array}$ & & & $1-3$ & 4 & 1 & 4,5 & 2,5 & 1 & - & 1,5 & 4 & 1,5 & 3 & - & 1 & $2-11$ & - & 1,2 & 8,9 & yes & \\
\hline Taylor et al.[23] & & & $1-3$ & 4 & 2 & 1 & 2 & 1 & - & 3 & 4 & 1 & 9 & - & 1 & $1-4$ & - & 1,2 & 7,8 & yes & \\
\hline $\begin{array}{l}\text { Cake et } \\
\text { al.[24] }\end{array}$ & & & $1-3$ & 4 & 1 & 1 & 1,5 & 1,6 & - & 1 & - & 3,5 & 7 & - & 1 & $\begin{array}{r}1,2 \\
4-7 \\
\end{array}$ & - & $1-5$ & $2,3,6$ & yes & \\
\hline $\begin{array}{l}\text { Darcy et } \\
\text { al.[25] }\end{array}$ & & & $1-3$ & 4 & 1 & 1 & 2,3 & 2 & - & 1 & 2 & 1,4 & 5 & - & - & $1-3$ & - & 1,2 & $3-5$ & no & \\
\hline $\begin{array}{l}\text { Epari et } \\
\text { al.[26] }\end{array}$ & & & $1-3$ & 4 & 1 & 1 & 2,3 & 1,3 & 2 & 1 & - & 5 & 6 & 1 & 1 & $3-6$ & - & $1,4,8$ & 10,11 & yes & \\
\hline Kim et al.[27] & & & $1-4$ & 5 & 1 & & $\begin{array}{r}2,3 \\
5,7\end{array}$ & 1 & - & $\begin{array}{c}1,3, \\
6\end{array}$ & 1 & 6,7 & 8 & - & 1,2 & $2-5$ & - & $1-11$ & 12,13 & yes & \\
\hline $\begin{array}{l}\text { Pendegrass et } \\
\text { al.[28] }\end{array}$ & & & 1,2 & 2 & 2 & 2 & $1-5$ & 2 & - & 2 & 2 & 4,5 & 6 & - & 1 & $2-5$ & - & $1-5$ & 6 & no & \\
\hline Polk et al.[29] & & & $1-6$ & 7 & 2 & 2,3 & $2-4,6$ & 2 & 2 & 2 & 2 & $3-6$ & 7 & - & - & $1-5$ & - & $1-6$ & $7-10$ & yes & \\
\hline Tapper et al.[30] & & & $1-5$ & 5 & 2 & 2 & 2 & 1,2 & - & 3 & 1 & 3,4 & 5 & - & 1 & $2-7$ & - & $1-7$ & 8 & yes & \\
\hline $\begin{array}{l}\text { Beveridge et } \\
\text { al.[31] }\end{array}$ & & & $1-3$ & 4 & 1 & 1 & $1-9$ & 1,3 & - & 1,2 & 2 & $2-4$ & $10-12$ & - & - & $1-5$ & - & $1-9$ & 10 & yes & \\
\hline $\begin{array}{l}\text { Herfat et } \\
\text { al.[32] }\end{array}$ & & & $1-6$ & 6 & 6 & 1 & $\begin{array}{r}1-3, \\
6-8 \\
\end{array}$ & 1 & - & 1,7 & - & 2 & 9 & - & - & $1-7$ & - & $1-5$ & 6 & yes & \\
\hline & $\stackrel{巳}{\stackrel{\Xi}{E}}$ & & & & & & & & & & & & & & & & & & & & \\
\hline
\end{tabular}




\begin{tabular}{|c|c|c|c|c|c|c|c|c|c|c|c|c|c|c|c|c|c|c|}
\hline $\begin{array}{l}\text { Hobbs-Chell } \\
\text { et al.[33] }\end{array}$ & 1,2 & 2 & 3 & 3 & 4 & 3 & 3 & 4 & 3 & 4 & 5 & - & - & 5 & - & 6 & 6 & yes \\
\hline $\begin{array}{l}\text { Shelton et } \\
\text { al.[34] }\end{array}$ & $1-8$ & 9 & & 4 & $2,3,5$ & 4 & - & 4 & - & $5-8$ & 7,8 & - & - & $1-4$ & - & $1-4$ & 5 & yes \\
\hline $\begin{array}{l}\text { Agostinho et } \\
\text { al.[35] }\end{array}$ & $1-6$ & 7 & 1 & 2 & 4,8 & 2 & 3 & 4,5 & 2 & $6-8$ & 9 & - & 1 & $2-5$ & - & $1-6$ & $7-15$ & yes \\
\hline $\begin{array}{l}\text { Frank et } \\
\text { al.[36] }\end{array}$ & $1-3$ & 4 & 1 & 1 & $3-5$ & 2 & - & 3 & 1 & 3,4 & 6,7 & - & 1 & $2-5$ & - & $1-5$ & 6,7 & yes \\
\hline $\begin{array}{l}O^{\prime} \text { Brien et } \\
\text { al.[37] }\end{array}$ & $1-3$ & 4 & 1 & 1 & 3,4 & 2 & - & 3 & 2 & 3 & 4,6 & - & 1 & $2-5$ & - & $1-7$ & $8-10$ & yes \\
\hline $\begin{array}{l}\text { Cake et } \\
\text { al.[38] }\end{array}$ & $1-4$ & 4 & 1 & 1 & $2-5$ & 1 & 1 & 2 & - & 3,5 & 7 & - & - & $1-7$ & - & $1-5$ & $6-8$ & yes \\
\hline $\begin{array}{l}\text { Faria et } \\
\text { al.[39] }\end{array}$ & $1-4$ & 5 & 1 & 1 & 3,4 & 1 & 2 & 5 & 1 & $6-8$ & 9 & - & - & 1,2 & - & $1-5$ & $6-8$ & yes \\
\hline $\begin{array}{l}\text { Valentin et } \\
\text { al.[40] }\end{array}$ & 1 & 1 & 2 & 2 & 3 & 2 & - & 3 & - & 4 & 5 & - & 6 & 6 & - & 7,8 & 9 & yes \\
\hline $\begin{array}{l}\text { Mora-Macías } \\
\text { et al.[41] }\end{array}$ & $1-4$ & 5 & 1 & 1 & 4,8 & 1 & - & 4 & 3 & 4,5 & 6,7 & - & 1 & $1-7$ & - & $1-9$ & 10,11 & yes \\
\hline $\begin{array}{l}\text { Safayi et } \\
\text { al.[42] }\end{array}$ & $1-3$ & 3 & 1 & 1 & 2,3 & 1 & 1,2 & 3 & 2 & 3 & 4,5 & 1 & 1 & $2-8$ & - & $1-3$ & 4,5 & yes \\
\hline $\begin{array}{l}\text { Wilson et } \\
\text { al.[43] }\end{array}$ & $1-4$ & 5 & 1 & 1 & $\begin{array}{c}2,3 \\
10 \\
11 \\
15,1\end{array}$ & $4-6$ & 1 & 2,3 & - & 3,14 & 19 & - & - & $1-9$ & - & $1-6,8$ & 7,8 & yes \\
\hline
\end{tabular}

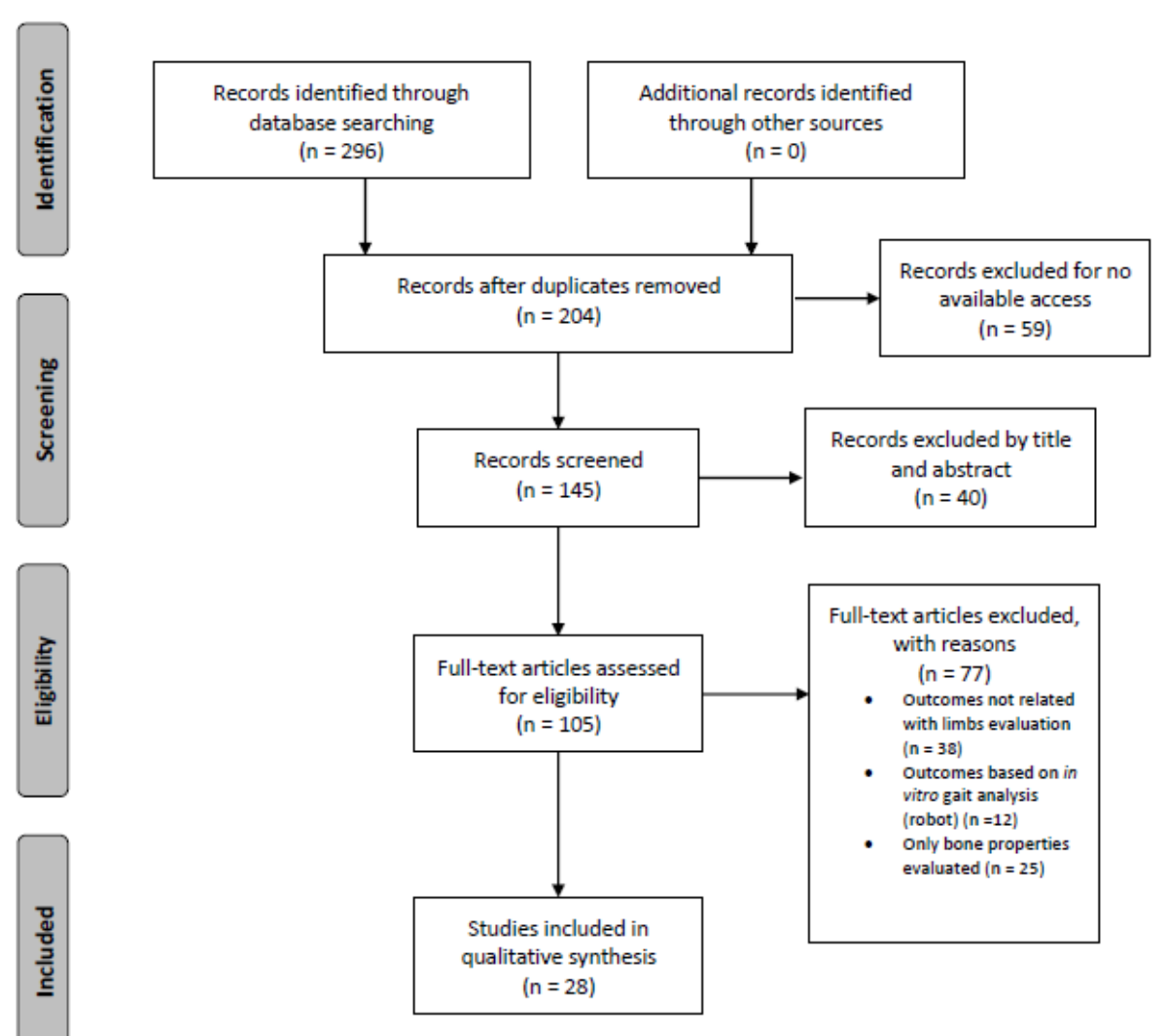

Fig 1: Flow diagram detailing the literature search and selection process.

Briefly, there was no study related with osteoporosis. The clinical conditions were mainly orthopedic issues related to bone healing [13,19,26,41], reattachment of the patellar tendon or implants [20,21,28], meniscectomy [24,31,34,38], stifle's ligaments surgery [30,32,36,37], spinal cord injuries $[42,43]$ or there was no clinical condition associated $[17,18,22,23,25,27,29,33,35,39,40]$. Even so, the most frequent parameters evaluated these studies 
were related to ground reaction force (GRF), stance/swing phase duration, stride length, gait cycle duration and the variations of stifle joint angles during gait cycle.

Ground reaction force. Authors according to their aims, analysed the (vertical) GRF for different limbs, normalizing or not the values for the animal's bodyweight. Kaspar et al. [19], Epari et al. [26] and Taylor et al. [23] only calculated the maximum GRF of the affected limb, like Frank et al. [36], but in their study they normalized to the body weight. Oddy et al. [20], Pendegrass et al. [28] using a custom-written software, calculated the mean peak vertical GRF for hind limbs, normalized for the weight of the animal and presented the result as a percentage of the contralateral hind limb, while Beveridge et al. [31], Tapper et al. [18] and Tapper et al. [22] only calculated hind limbs peak vertical GRF. Seebeck et al. [13], Herfat et al. [32], Duda et al. [17], Cake at al. [38] and Cake et al. [24] recorded for all four limbs the peak vertical GRF, normalizing after to the animal's bodyweight. Mora-Macías et al. [41], Pendegrass et al. [21], measure the vertical GRF for each limb and normalized to the sheep weight, in order to calculate the symmetry index. Shelton et al. [34], Kim et al. [27] and Agostinho et al. [35] recorded for all limb the peak vertical GRF as the animal moved through the gait cycle and then obtain the peak vertical force weight distribution for each limb, minimizing the influence of both weight and the velocity of the animal.

Related to stance and swing phase duration. The stance phase can be calculated as a percentage of the gait cycle dividing the time the animal was in stance phase by the time it took to complete one gait cycle (Shelton et al. [34], Tapper et al. [22] and Tapper et al. [30]), only the single hind limb stance duration (Herfat et al. [32]) or the duration of stance and swing phases, and then represent them in percentage of total gait cycle (Safayi et al. [42], Wilson et al. [43], Kim et al. [27], Agostinho et al. [35]).

Related to stride length and gait cycle duration. Shelton et al. [34], Frank et al. [36], Safayi et al. [42], Wilson et al. [43], Tapper et al. [18], Kim et al. [27], Hobbs-Chell et al. [33], Agostinho et al. [35] and Valentin et al. [40] evaluated the stride length as the distance from hoof strike to hoof strike, from the same limb. Safayi et al. [42], Wilson et al. [43] Tapper et al. [18], Tapper et al. [22], Kim et al. [27] and Agostinho et al. [35] use the same criteria described to calculate the duration of the gait cycle.

Related to stifle joint angles during gait cycle. Oddy et al. [20], Taylor et al. [23], Polk et al. [29], Faria et al. [39] in their study recorded the positional change in sagittal plane of reflective markers strategically placed, calculating the range of movement of flexion/extension at the stifle joint, while Beveridge et al. [31], in their study analyzed changes in abduction/adduction at stifle joint during gait cycle. On the other way, Tapper et al. [30], Frank et al. [36], O'Brien et al. [37], Tapper et al. [18], Tapper et al. [22] and Darcy et al. [25], by the method detailed by Grood et al. [44], described the angular kinematics of the stifle joint during distinct times during the gait cycle, using three joint angles: flexion/extension, abduction/adduction and external/internal rotation.

The synthesis of the data extraction from all included articles is present in Table 2. 
Table 2: Summary of the results

\begin{tabular}{|c|c|c|c|c|c|c|c|}
\hline \multirow{2}{*}{$\begin{array}{l}\text { First Author, } \\
\text { Year }\end{array}$} & \multirow{2}{*}{$\frac{\text { Participants }}{\mathbf{N}}$} & \multicolumn{5}{|c|}{ Instruments } & \multirow{2}{*}{ Parameters evaluated } \\
\hline & & FP & TR & CVS & RM & PSP & \\
\hline $\begin{array}{l}\text { Seebek et al. } \\
{[13]}\end{array}$ & 64 & & & $\mathrm{X}$ & $\mathrm{X}$ & $\mathrm{X}$ & $\begin{array}{l}\text { Maximum GRF, maximum contact area and contact } \\
\text { time while walk. }\end{array}$ \\
\hline $\begin{array}{l}\text { Kaspar et al. } \\
{[19]}\end{array}$ & 12 & & & & & $\mathrm{X}$ & Maximum force, contact area, and contact time. \\
\hline $\begin{array}{l}\text { Epari et al. } \\
{[26]}\end{array}$ & 6 & $\mathrm{X}$ & & $\mathrm{X}$ & & & Mean peak GRF during gait cycle. \\
\hline $\begin{array}{l}\text { Mora- } \\
\text { Macías et al. }\end{array}$ & 6 & $\mathrm{X}$ & & & & & $\begin{array}{l}\text { The peak, the mean and the impulse of the VGRF were } \\
\text { calculated during the stance phase for each limb. }\end{array}$ \\
\hline $\begin{array}{l}\text { Oddy et al. } \\
{[20]}\end{array}$ & 26 & $\mathrm{X}$ & & $\mathrm{X}$ & $\mathrm{X}$ & & $\begin{array}{l}\text { Mean peak VGRF; stifle joint angle during gait; gait } \\
\text { speed. }\end{array}$ \\
\hline $\begin{array}{l}\text { Pendegrass } \\
\text { et al. [21] }\end{array}$ & 8 & $\mathrm{X}$ & & & & & Mean peak VGRF. \\
\hline $\begin{array}{l}\text { Pendegrass } \\
\text { et al. [28] }\end{array}$ & 12 & $\mathrm{X}$ & & & & & Mean peak VGRF. \\
\hline $\begin{array}{l}\text { Cake et al. } \\
{[24]}\end{array}$ & 18 & $\mathrm{X}$ & & & & & Mean VGRF. \\
\hline $\begin{array}{l}\text { Beveridge et } \\
\text { al. [31] }\end{array}$ & 9 & $\mathrm{X}$ & & $\mathrm{X}$ & $\mathrm{X}$ & & Peak VGRF; stifle joint angles during gait cycle. \\
\hline $\begin{array}{l}\text { Shelton et } \\
\text { al. [34] }\end{array}$ & 9 & $\mathrm{X}$ & & $\mathrm{X}$ & & & Peak VGRF; stride length and stance phase. \\
\hline Cake et al. & 24 & $\mathrm{X}$ & & & & & Peak VGRF. \\
\hline $\begin{array}{l}\text { Tapper et al. } \\
\text { [30] }\end{array}$ & 8 & & & $\mathrm{X}$ & $\mathrm{X}$ & & $\begin{array}{l}\text { Period of the gait cycle; duration of the stance phase; } \\
\text { angular velocity of stifle joint. }\end{array}$ \\
\hline $\begin{array}{l}\text { Herfat et al. } \\
{[32]}\end{array}$ & 10 & $\mathrm{X}$ & $\mathrm{X}$ & & & & $\begin{array}{l}\text { Fore and hind limb average VGRFs, peak hind limb } \\
\text { VGRF and single hind limb stance duration during the } \\
\text { gait cycle. }\end{array}$ \\
\hline $\begin{array}{l}\text { Frank et al. } \\
{[36]}\end{array}$ & 35 & $\mathrm{X}$ & & $\mathrm{X}$ & $\mathrm{X}$ & & $\begin{array}{l}\text { Peak VGRF; angular kinematics of the stifle joint } \\
\text { during gait cycle and average stride. }\end{array}$ \\
\hline $\begin{array}{l}\text { O'Brien et } \\
\text { al. }[37]\end{array}$ & 29 & & & $\mathrm{X}$ & $\mathrm{X}$ & & Stifle joint angles during gait cycle \\
\hline $\begin{array}{l}\text { Safayi et al. } \\
{[42]}\end{array}$ & 17 & & $\mathrm{X}$ & $\mathrm{X}$ & $\mathrm{X}$ & & $\begin{array}{l}\text { Stride duration; stance duration; swing duration; } \\
\text { percentage of stance and swing; swing velocity of hoof; } \\
\text { range of hoof elevation at swing phase; distance } \\
\text { between lateral limbs; hock joint flexion-extension } \\
\text { range during stance and swing; hock joint angular } \\
\text { velocity during stance and swing. }\end{array}$ \\
\hline $\begin{array}{l}\text { Wilson et al. } \\
{[43]}\end{array}$ & 6 & & & $\mathrm{X}$ & $\mathrm{X}$ & & $\begin{array}{l}\text { Gait cycle duration; stance duration; swing duration; } \\
\text { ratio of stance and swing to stride; distance between } \\
\text { contralateral limbs; lateral deviation of hoof during } \\
\text { swing; forward velocity of hoof during swing; vertical } \\
\text { velocity of hoof during swing; range of hoof height } \\
\text { during swing; stride length; min hock joint angle during } \\
\text { stance; max hock joint angle during stance; full range } \\
\text { of hock joint during swing; hock joint angular velocity } \\
\text { during swing. }\end{array}$ \\
\hline $\begin{array}{l}\text { Duda et al. } \\
{[17]}\end{array}$ & 7 & $\mathrm{X}$ & & & & & 3D - GRF. \\
\hline $\begin{array}{l}\text { Tapper et al. } \\
{[18]}\end{array}$ & 5 & $\mathrm{X}$ & $\mathrm{X}$ & $\mathrm{X}$ & $\mathrm{X}$ & & $\begin{array}{l}\text { Peak VGRF; stifle joint angle during gait; gait cycle } \\
\text { duration }\end{array}$ \\
\hline $\begin{array}{l}\text { Tapper et al. } \\
{[22]}\end{array}$ & 8 & $\mathrm{X}$ & & $\mathrm{X}$ & $\mathrm{X}$ & & $\begin{array}{l}\text { Stride times and timing of the stance and swing phases } \\
\text { of the gait cycle; stifle joint angles and angular } \\
\text { velocity; peak VGRF during loading, peak posterior } \\
\text { GRF during loading, peak anterior GRF during push- } \\
\text { off, and peak medial GRF during push-off. }\end{array}$ \\
\hline
\end{tabular}




\begin{tabular}{|c|c|c|c|c|c|c|c|}
\hline $\begin{array}{l}\text { Taylor et al. } \\
\text { [23] }\end{array}$ & 3 & $\mathrm{X}$ & & $\mathrm{X}$ & $\mathrm{X}$ & & $\begin{array}{l}\text { Average peak of GRFs; hip and stifle flexion } \\
\text { extension during gait cycle. }\end{array}$ \\
\hline $\begin{array}{l}\text { Darcy et al. } \\
{[25]}\end{array}$ & 4 & $\mathrm{X}$ & & $\mathrm{X}$ & $\mathrm{X}$ & & $\begin{array}{l}\text { Stifle joint translations and rotations durance the gait } \\
\text { cycle. }\end{array}$ \\
\hline $\begin{array}{l}\text { Kim et al. } \\
{[27]}\end{array}$ & 7 & & & & $\mathrm{X}$ & $\mathrm{X}$ & $\begin{array}{l}\text { Gait cycle duration; stance phase duration; swing phase } \\
\text { duration; stride length; limb velocity; peak VGRF; } \\
\text { vertical impulse. }\end{array}$ \\
\hline $\begin{array}{l}\text { Polk et al. } \\
{[29]}\end{array}$ & 15 & & $\mathrm{X}$ & $\mathrm{X}$ & & & Stifle joint angle during gait. \\
\hline $\begin{array}{l}\text { Hobbs-Chell } \\
\text { et al. [33] }\end{array}$ & 10 & & & $\mathrm{X}$ & & & $\begin{array}{l}\text { Time taken in seconds to travel } 10 \mathrm{~m} \text {; number of strides } \\
\text { taken in } 10 \mathrm{~m} \text {; stride length and limb velocity. }\end{array}$ \\
\hline $\begin{array}{l}\text { Agostinho et } \\
\text { al. [35] }\end{array}$ & 21 & & & $\mathrm{X}$ & $\mathrm{X}$ & $\mathrm{X}$ & $\begin{array}{l}\text { Gait cycle time; stance time; swing time; stride length; } \\
\text { percentage of stance and swing phases in gait cycle; } \\
\text { peak VGRF and vertical impulse. }\end{array}$ \\
\hline $\begin{array}{l}\text { Faria et al. } \\
{[39]}\end{array}$ & 14 & & & $\mathrm{X}$ & $\mathrm{X}$ & $\mathrm{X}$ & $\begin{array}{l}\text { Flexion and extension joint angles and angular velocity } \\
\text { were determined for the shoulder, elbow, carpal, hip, } \\
\text { stifle, and tarsal joints. }\end{array}$ \\
\hline $\begin{array}{l}\text { Valentin et } \\
\text { al. }[40]\end{array}$ & 5 & & $\mathrm{X}$ & $\mathrm{X}$ & $\mathrm{X}$ & & $\begin{array}{l}\text { Movement cycle duration; vertical trunk movement; } \\
\text { stride height; stride length and percentage of movement } \\
\text { cycle at stance. }\end{array}$ \\
\hline
\end{tabular}

FP: Force Plate; CVS: Camera Video System; RM: Reflective Markers; PSP: Pressure Sensitive Platform; VGRF: Vertical Ground Reaction Force; GRF - Ground Reaction Force

\section{Discussion}

Analysing all these outcome measure collected from the 28 studies included, the most recurrent were the calculation of the mean peak (vertical) GRF [13,17-24,26-28,31,32,34-36,38,41], gait cycle duration [18,27,30,35,37,41,43], stance-swing phase duration [27,30,32,34,35,41-43], percentage of stance/swing phase in gait $[22,35,40,42]$, stride length $[27,33-36,40,43]$ and the stifle joint angles during gait [22,23,25,29-31,36,37,39]. The fact that several of these parameters were measured simultaneously, allowed a more complete conclusion once all parameters are related with each other [35]. Hence, in future studies performed in sheep with osteoporosis, it should be considered to use more than one biomechanical parameter. These parameters might be also used to assess the effects of different treatment. However, it's important to consider that some of these parameters have a large variability of results, like the percentage of stance/swing phase during gait, not being recommend drawing conclusions based on the isolated parameter. Agostinho et al. [35] and Kim et al. [27] in their studies with healthy sheep concluded that for the forelimb, the stance phase ranges between 58,86 - 66,31\% and swing phase from 41,49-33,69\%; and for hind limbs the stance phase ranged between $61,88-68,89 \%$ and swing phase from $31,11-38,85 \%$.

However, although parameters related to gait analysis seem to be the best evaluation in this animal model, the methods already used in sheep to measure those can have limitations. It is very important to plan an habituation period with this kind of equipment (treadmill / pressure sensitive walking or walking guided for a halter), that normally occur several days before the trials [27]. Additionally, the average speed of the treadmill in most of the studies were $1 \mathrm{~m} / \mathrm{s}$ because a velocity between 1,1 - 1,3 $\mathrm{m} / \mathrm{s}$ was considered comfortable for the sheep (while for cats and dogs the velocity range from $0,6-0,81$ and $0,5-1,14 \mathrm{~m} / \mathrm{s}$ respectively). Yet, this may not be enough to abolish the stress, making the sheep difficult to analyze or even refuse to walk [27].

The presence of osteoporosis can have serious implications because this increases the risk of falls the major cause of unintentional injury and hospitalization in people over 65 years $[45,46]$. In 2010, 27 million Europeans were estimated to have osteoporosis, being over 80\% women [47]. These disease is characterized by low bone mass and a disruption of the normal trabecular architecture, leading to increased bone fragility and a rise of the risk of sustaining fractures from falls $[48,49]$. In fact, fractures represent the most profound consequences of reduced bone mineral density $[45,46]$. 
In many patients, this may cause loss of independence, aggravation of pain and a deterioration in health-related quality of life, which may be associated with limitations in activities and the restriction of their participation [50]. One of the most common is fracture of the hip, with slow recovery and rehabilitation often incomplete, leading many patients permanently to a nursing home [50]. Therefore, due to the increasing threat posed by osteoporosis, there is a need to search for new and better drugs that inhibit its development. To test them it has become necessary to find an animal model, which will allow further progress in work to control the disease [4].

The exclusive evaluation of the bone structure makes the assessment incomplete, because we don't provide information about the impact of therapy in the daily life of the animal, for example, how therapy affects the capacity of movement, or more importantly, if osteoporosis has any kind of impact on the animal's ability to relate to the environment in which it is inserted [27]. So, in order to clarify all these aspects, parameters related to gait analysis of animals, in particular of the sheep, can be an accurate, quantitative, and objective method by which to document limb function during normal activities or to analyze changes that are related with diseases, like the osteoporosis [27].

\section{Summary}

Several methods of bone mass evaluation are assessed in the literature, such as biochemical markers, densitometry, histomorphometry, and bone mechanical testing used for monitoring and evaluation of the animal models in preventive or therapeutic strategies for osteoporosis [51,52]. However, the study of integrated assessment, like gait biomechanics, is still novel [53]. Due to the negative impact that osteoporosis has on people's lives, it is essential to know the effect of therapies, besides the evaluation of the bone properties, and we should consider parameters related to function and disability in animal models, and to explore the relationship between structure and function [50]. Recently, functional assessments started to be considered in many different animal models like rats, for stroke model [7], for peripheral nerve injury [8,11] and others [54], dogs [53,55] and minipigs [56].

Since gait assumes the most important task in the sheep routine, evaluation of such parameters should be considered. Through this systematic review, it was possible to notice that in studies already carried out in sheep, parameters like the mean peak VGRF, gait cycle duration, stance/swing phase duration, percentage of stance/swing phase in gait cycle, stride length and the stifle joint angles during gait cycle were already used to evaluate the gait of these ovine to study different orthopedic conditions but not osteoporosis.

The development of bone and musculoskeletal models for simulation may also have an important role in the future.[57] Moreover, muscle activity during gait cycle, and the tibiofemoral contact forces could also be related with decrease of bone mineral density and functional impairment. Therefore, the above parameters can be used in future research using sheep with osteoporosis, however more studies are required to prove their reliability in this disease and population.

\section{Acknowledgments}

This research work was supported by the Portuguese Foundation for Science and Technology (FCT) and Centro2020 through Project References UID/Multi/04044/2013; PAMI - ROTEIRO/0328/2013 $\left(\mathrm{N}^{\circ}\right.$ 022158) and BioMaTE project - A novel bio-manufacturing system to produce bioactive scaffolds for tissue engineering reference PTDC/EMS-SIS/7032/2014. 


\section{References}

[1] R.J. Moore, Validation of the sheep as a large animal model for the study of vertebral osteoporosis, (2009) 244-253.

[2] M. Egermann, J. Goldhahn, E. Schneider, Animal models for fracture treatment in osteoporosis, Osteoporos. Int. 16 (2005) 129-138.

[3] A.S. Turner, Animal models of osteoporosis: necessity and limitations, Eur. Cell. Mater. 1 (2001) 66-81.

[4] Z. Kiełbowicz, A. Piątek, J. Bieżyński, P. Skrzypczak, E. Chmielewska, P. Kafarski, J. Kuryszko, Improvement of large animal model for studying osteoporosis, Bull Vet Inst Pulawy 59 (2015) 123-128.

[5] J. Zhao, Y. Jiang, C.F. Njeh, R. Bouillon, P. Geusens, H.K. Genant, Animal Studies, in: Phys. Meas. Bone, Bristol and Philadelphia: Institute of Physics Publishing, 2003: pp. 571592.

[6] C. Ruosi, F. Querques, F. Granata, G. Colella, S. Liccardo, B. Lombardo, L. Pastore, Cellular and Animal Models for the Identification of Osteoporosis Determinants Increasing Vertebral Compression Fractures Risk, J Osteopor Phys Act 3 (2015) 1-9.

[7] K.L. Schaar, M.M. Brenneman, S.I. Savitz, Functional assessments in the rodent stroke model., Exp. Transl. Stroke Med. 2 (2010) 1-11.

[8] S. Amado, Functional Assessment after Peripheral Nerve Injury - Kinematic Model of the Hindlimb of the Rat, Faculdade de Motricidade Humana da Universidade Técnica de Lisboa, 2012.

[9] C.S. Howard, D.C. Blakeney, J. Medige, J.M. Owen, C.A. Peimer, Functional assessment in the rat by ground reaction forces, J. Biomech. 33 (2000) 751-757.

[10] A.S.P. Varejão, A.M. Cabrita, J.A. Patrício, J. Bulas-Cruz, R.C. Gabriel, P. Melo-Pinto, P.A. Couto, M.F. Meek, Functional assessment of peripheral nerve recovery in the rat: Gait kinematics, Microsurgery 21 (2001) 383-388.

[11] A.S.P. Varejão, P. Melo-Pinto, M.F. Meek, V.M. Filipe, J. Bulas-Cruz, Methods for the experimental functional assessment of rat sciatic nerve regeneration, Neurol. Res. 26 (2004) 186-194.

[12] A. Biewener, Physical and biological properties and principles related to animal movement, in: Anim. Locomot., New York: Oxford Univ Pr, 2003: pp. 1-14.

[13] P. Seebeck, M.S. Thompson, A. Parwani, W.R. Taylor, H. Schell, G.N. Duda, Gait evaluation : A tool to monitor bone healing?, Clin. Biomech. 20 (2005) 883-891.

[14] D. Jevens, C. DeCamp, J. Hauptman, T. Braden, M. Richter, R. Robinson, Use of force-plate analysis of gait to compare two surgical techiques for treatment of cranial cruaciate ligament rupture in dogs, Am J Vet Res 57 (1996) 389-393.

[15] C. Kilkenny, W.J. Browne, I.C. Cuthill, M. Emerson, D.G. Altman, Improving Bioscience Research Reporting: The ARRIVE Guidelines for Reporting Animal Research, PLoS Biol. 8 (2010) e1000412.

[16] D. Moher, A. Liberati, J. Tetzlaff, D.G. Altman, Preferred Reporting Items for Systematic Reviews and Meta-Analyses: The PRISMA Statement, PLoS Med. 89 (2009) e1000097.

[17] G.N. Duda, K. Eckert-hu, R. Sokiranski, A. Kreutner, R. Miller, L. Claes, Analysis of interfragmentary movement as a function of musculoskeletal loading conditions in sheep, J. Biomech. 31 (1998) 201-210. 
[18] J.E. Tapper, J.L. Ronsky, M.J. Powers, C. Sutherland, T. Majima, C.B. Frank, N.G. Shrive, In Vivo Measurement of the Dynamic 3-D Kinematics of the Ovine Stifle Joint, J. Biomech. Eng. 126 (2004) 301.

[19] K. Kaspar, H. Schell, P. Seebeck, M.S. Thompson, M. Schütz, N.P. Haas, G.N. Duda, Angle Stable Locking Reduces Interfragmentary Movements and Promotes Healing After Unreamed Nailing, J. Bone Jt. Surg. 87-A (2005) 2028-2037.

[20] M.J. Oddy, C.J. Pendegrass, A.E. Goodship, S.R. Cannon, T.W.R. Briggs, G.W. Blunn, Extensor mechanism reconstruction after proximal tibial replacement, J. Bone Jt. Surg. 87-B (2005) 873-878.

[21] C.J. Pendegrass, M.J. Oddy, S. Sundar, S.R. Cannon, A.E. Goodship, G.W. Blunn, The novel use of resorbable Vicryl mesh for in vivo tendon reconstruction to a metal prosthesis, J. Bone Jt. Surg. 88-B (2006) 1245-1251.

[22] J.E. Tapper, S. Fukushima, H. Azuma, G.M. Thornton, J.L. Ronsky, N.G. Shrive, C.B. Frank, Dynamic In Vivo Kinematics of the Intact Ovine Stifle Joint, J. Orthop. Res. 24 (2006) 782 792.

[23] W.R. Taylor, R.M. Ehrig, M.O. Heller, H. Schell, P. Seebeck, G.N. Duda, Tibio-femoral joint contact forces in sheep, J. Biomech. 39 (2006) 791-798.

[24] M. Cake, R. Read, S. Edwards, M.M. Smith, D. Burkhardt, C. Little, P. Ghosh, Changes in gait after bilateral meniscectomy in sheep : effect of two hyaluronan preparations, J. Orthop. Sci. 13 (2008) 514-523.

[25] S.P. Darcy, J.M. Rosvold, J.E. Beveridge, D.T. Corr, J.J.Y. Brown, C.A. Sutherland, L.L. Marchuk, C.B. Frank, N.G.S. Ã, A comparison of passive flexion - extension to normal gait in the ovine stifle joint, J. Biomech. 41 (2008) 854-860.

[26] D.R. Epari, J. Lienau, H. Schell, F. Witt, G.N. Duda, Pressure, oxygen tension and temperature in the periosteal callus during bone healing - An in vivo study in sheep, Bone 43 (2008) 734-739.

[27] J. Kim, G.J. Breur, Temporospatial and kinetic characteristics of sheep walking on a pressure sensing walkway, Can. J. Vet. Res. (2008) 50-55.

[28] C.J. Pendegrass, S. Sundar, M.J. Oddy, S.R. Cannon, T. Briggs, G.W. Blunn, A comparison of augmentation techniques for reconstruction of the extensor mechanism following proximal tibial replacement in an experimental animal model, J. Bone Jt. Surg. 90 (2008) 535-541.

[29] J.D. Polk, J. Blumenfeld, D. Ahluwalia, Knee Posture Predicted From Subchondral Apparent Density in the Distal Femur: An Experimental Validation, Anat. Rec. 302 (2008) 293-302.

[30] J.E. Tapper, S. Fukushima, H. Azuma, C. Sutherland, L. Marchuk, G.M. Thornton, J.L. Ronsky, R. Zernicke, N.G. Shrive, C.B. Frank, Dynamic In Vivo Three-Dimensional ( 3D ) Kinematics of the Anterior Cruciate Ligament / Medial Collateral Ligament Transected Ovine Stifle Joint, J. Orthop. Res. (2008) 660-672.

[31] J.E. Beveridge, N.G. Shrive, C.B. Frank, Meniscectomy Causes Significant In Vivo Kinematic Changes and Mechanically Induced Focal Chondral Lesions in a Sheep Model, J. Orthop. Res. (2011) 1397-1405.

[32] S.T. Herfat, J.T. Shearn, D.L. Bailey, R.M. Greiwe, M.T. Galloway, C. Gooch, D.L. Butler, Effect of Surgery to Implant Motion and Force Sensors on Vertical Ground Reaction Forces in the Ovine Model, J. Biomech Eng. 133 (2013) 1-25. 
[33] H. Hobbs-chell, A.J. King, H. Sharratt, H. Haddadi, S.R. Rudiger, S. Hailes, A.J. Morton, A.M. Wilson, Data-loggers carried on a harness do not adversely affect sheep locomotion, Res. Vet. Sci. 93 (2012) 549-552.

[34] T.J. Shelton, J.P. Beck, R.D. Bloebaum, K.N. Bachus, Percutaneous Osseointegrated Prostheses for Amputees: Limb Compensation in a 12-Month Ovine model, J Biomech 44 (2011) 2601-2606.

[35] F.S. Agostinho, S.C. Rahal, F.A.P. Araújo, R.T. Conceição, C.A. Hussni, A.O. El-warrak, F.O.B. Monteiro, Gait analysis in clinically healthy sheep from three different age groups using a pressure-sensitive walkway, BMC Vet. Res. 8 (2012) 1-7.

[36] C.B. Frank, J.E. Beveridge, K.D. Huebner, B.J. Heard, J.E. Tapper, E.J.O.O. Brien, N.G. Shrive, Complete ACL / MCL Deficiency Induces Variable Degrees of Instability in Sheep with Specific Kinematic Abnormalities Correlating with Degrees of Early Osteoarthritis, J. Orthop. Res. 2 (2012) 384-392.

[37] E.J.O.O. Brien, J.E. Beveridge, K.D. Huebner, B.J. Heard, J.E. Tapper, N.G. Shrive, C.B. Frank, Osteoarthritis Develops in the Operated Joint of an Ovine Model following ACL Reconstruction with Immediate Anatomic Reattachment of the Native ACL, J. Orthop. Res. (2012) 1-9.

[38] M.A. Cake, R.A. Read, G. Cor, A. Daniel, D. Burkhardt, M.M. Smith, C.B. Little, Comparison of gait and pathology outcomes of three meniscal procedures for induction of knee osteoarthritis in sheep, Osteoarthr. Cartil. 21 (2013) 226-236.

[39] L.G. Faria, S.C. Rahal, F.S. Agostinho, B.W. Minto, L.M. Matsubara, W.T. Kano, M.S. Castilho, L.R. Mesquita, Kinematic analysis of forelimb and hind limb joints in clinically healthy sheep, BMC Vet. Res. 10 (2014) 1-5.

[40] S. Valentin, A. Essigbeck, I. Wolfram, T. Licka, Kinematic parameters of sheep walking on a treadmill, Vet. J. 202 (2014) 657-658.

[41] J. Mora-Macías, E. Reina-Romo, J. Morgaz, J. Domínguez, In Vivo Gait Analysis During Bone Transport, Ann. Biomed. Eng. (2015) 1-11.

[42] S. Safayi, N.D. Jeffery, S.K. Shivapour, M. Zamanighomi, T.J. Zylstra, J. Bratsch-Prince, S. Wilson, C.G. Reddy, D.C. Fredericks, G.T. Gillies, M.A. Howard III, Kinematic analysis of the gait of adult sheep during treadmill locomotion: Parameter values, allowable total error, and potential for use in evaluating spinal cord injury, J. Neurol. Sci. 358 (2015) 107-112.

[43] S. Wilson, K.O. Abode-Iyamah, J.W. Miller, C.G. Reddy, S. Safayi, D.C. Fredericks, N.D. Jeffery, N.A. Devries-Watson, S.K. Shivapour, S. Viljoen, B.D. Dalm, N. Katherine, M.D. Johnson, G.T. Gillies, M.A. Howard III, An ovine model of spinal cord injury An ovine model of spinal cord injury, J. Spinal Cord Med. (2016) 1-15.

[44] E.S. Grood, W.J. Suntay, A Joint Coordinate System for the Clinical Description of ThreeDimensional Motions: Application to the Knee, J. Biomech. Eng. 105 (1983) 136-144.

[45] A.M. Dellinger, J.A. Stevens, The injury problem among older adults : Mortality , morbidity and costs, J. Safety Res. 37 (2006) 519-522.

[46] D.C. Abreu, D.C. Trevisan, G.C. Costa, F.M. Vasconcelos, M.M. Gomes, A.A. Carneiro, The association between osteoporosis and static balance in elderly women, Osteoporos. Int. 21 (2010) 1487-1491.

[47] A. Svedbom, E. Hernlund, M. Ivergård, J. Compston, C. Cooper, J. Stenmark, E. V. McCloskey, B. Jönsson, J.A. Kanis, Osteoporosis in the European Union: a compendium of country-specific reports, Arch Osteoporos 8 (2013) 1-2. 
[48] S.R. Cummings, L.J. Melton III, Epidemiology and outcomes of osteoporotic fractures, Lancet 359 (2002) 1761-1767.

[49] P. Sambrook, C. Cooper, Osteoporosis, Lancet 367 (2006) 2010-2018.

[50] P. Lips, N.M. van Schoor, Quality of life in patients with osteoporosis, Osteoporos. Int. 16 (2005) 447-455.

[51] P.P. Lelovas, T.T. Xanthos, S.E. Thoma, G.P. Lyritis, I.A. Dontas, The Laboratory Rat as an Animal Model for Osteoporosis Research, Comp. Med. 58 (2008) 424-430.

[52] W.S. Jee, W. Yao, Overview: animal models of osteopenia and osteoporosis., J. Musculoskelet. Neuronal Interact. 1 (2001) 193-207.

[53] F.G. Vassalo, S.C. Rahal, F.S. Agostinho, M.J. Mamprim, A. Melchert, W.T. Kano, L. dos Reis Mesquita, D.P. Doiche, C. Newton, P. Schwarz, G. Harasen, H. Denny, S. Butterworth, R. Gillette, T. Angle, L. Fanchon, D. Grandjean, S. Fischer, A. Anders, I. Nolte, N. Schilling, C. Horstman, M. Conzemius, R. Evans, W. Gordon, T. LeQuang, P. Maitre, T. Roger, E. Viguier, W. Gordon-Evans, R. Evans, M. Conzemius, A. Souza, A. Tatarunas, J. Matera, M. Besancon, M. Conzemius, T. Derrick, M. Ritter, B. Lascelles, S. Roe, E. Smith, L. Reynolds, J. Markham, D. Marcellin-Little, M. Bergh, S. Budsberg, D. Millis, D. Levine, K. Voss, J. Imhof, S. Kaestner, P. Montavon, M. Olmstead, A. Dunbar, J. Kim, K. Kazmierczak, G. Breur, M. Quinn, N. Keuler, Y. Lu, M. Faria, P. Muir, M. Markel, S. Budsberg, D. Jevens, J. Brown, T. Foutz, C. DeCamp, L. Reece, V. Light, J. Steiss, R. Montgomery, P. Rumph, J. Wright, F. Agostinho, S. Rahal, F. Araujo, R. Conceição, C. Hussni, A. El-Warrak, F. Monteiro, Gait analysis in dogs with pelvic fractures treated conservatively using a pressuresensing walkway, Acta Vet. Scand. 57 (2015) 68.

[54] R. de Haas, F.G. Russel, J.A. Smeitink, Gait analysis in a mouse model resembling Leigh disease, Behav. Brain Res. 296 (2016) 191-198.

[55] W.T. Kano, S.C. Rahal, F.S. Agostinho, L.R. Mesquita, R.R. Santos, F.O.B. Monteiro, M.S. Castilho, A. Melchert, Kinetic and temporospatial gait parameters in a heterogeneous group of dogs, Bmc Vet. Res. 12 (2016) 1-9.

[56] P.L.T. Justolin, S.C. Rahal, F.S. Agostinho, M.J. Mamprim, C.R. Teixeira, D.P. Doiche, V.R. Babicsak, Radiographic and computed tomographic evaluation and gait analysis of Brazilian minipigs with syndactyly, Am. J. Vet. Res. 77 (2016) 976-982.

[57] Z.F. Lerner, B.C. Gadomski, A.K. Ipson, K.K. Haussler, C.M. Puttlitz, R.C. Browning, Modulating Tibiofemoral Contact Force in the Sheep Hind Limb via Treadmill Walking: Predictions From an Opensim Musculoskeletal Model, J. Orthop. Res. (2015) 1128-1133. 